\title{
STATUTORY LIENS UNDER SECTION 67c OF THE BANKRUPTCY ACT
}

FEDERAL tax liens and a proliferation of state statutory liens and priorities, enacted by legislatures to faror such local creditors as wage earners, landlords, contractors, and taxing agencies, at one time threatened to disrupt the order of payment contemplated by the Bankruptcy .tct. ${ }^{1}$ Prior to 1938, statutory lienors satisfied their claims before: junirr lienors on the same property, creditors with priorities granted by Section 6 fa of the Banlruptey Act, and general creditors.2 And, unlike consenstal liens, statutory liens could not be voided as preferential transfers. ${ }^{3}$ Moreover, holders oi state statutory priorities received a seventh priority under Section G4a, entitling them to satisfy their claims before general creditors. ${ }^{4}$ The claims of favored creditors, particularly wage and tax lienors and the multiple state priority holders, often exhausted the bankrupt's estate before either Section Gota priorities or general creditors received any benefit." As a result, Congress took remedial action.

The 1938 Bankruptcy Act amendments withdrew recugnition entirely from state statutory priorities ${ }^{B}$ and partially restricted the protection afforded statutory liens. Section $67 \mathrm{~b}$, when read with $67 \mathrm{c}$, continues the immunity of statutory liens on realty from the trustee's nower to void preierential transfers. ${ }^{7}$ But under $67 \mathrm{c}$, all liens of distress for rent, whether or not statutory, on personal property, which have not been enforced by sale prior to

1. Axalysis of H.R.-128\$9, 74th Cong., 2d Sess. 212 (193u) ; H.R. Rep. Au. 1209, 75th Cong., 1st Sess. 16 (1937) ; 4 Collyer, Bankstipta 163 n.1 (14th cd., Mourre, 1942).

2. Miners' Sav. Bank of Pittston v. Joyce, 97 F.2d 973 (3d Cir. 193S); Ita re KerbyDennis Co., 95 Fed. 116 (7th Cir. 1899). Sec In re Van Winkle, 20 F. Supp.711, 713 (W.D. Ky. 1943). Cf. In re Edmunds, 30 F. Supp. 934 (M.D. Pa. 1940 ) (lien of distress for rent).

3. 3 COLLIER, op. cit. supra note 1, at 799.

4. 44 Stat. 666 (1926). In $r c$ Consolidated Iron \& Stcel Co., 76 1.2d 837 (wh Cir. 1935); In re Lewis, 99 Fed. 935 (D. Mass. 1900); In re Wright, 95 Fod. \&U7 (D. Mlass. 1899).

5. See materials cited note 1 sitpra.

6. Except rent priorities, which were given 5th (last) place in the federal priority scheme, and restricted to "rent which is legally due and owing for the actual use and occupancy of the premises affected, and which accrued within three months bafore the date of bankruptcy." 52 STAT. 874 (1938), 11 U.S.C. $\$ 104$ (a) (5) (1940).

7. Section 67 (b) provides: "The provision of section $60 \ldots$ notwithstanding, statutury liens ... may be valid against the trustee, even though arising or perfected while the debtor is insolvent and within four months prior to the filing of the petition. ..." 52 Srnt. 876 (1938), as amended, 66 Stat. 427, 11 U.S.C.A. $\$ 107$ (b) (Sugp. 1952). The word "may" has been construed as mandatory. Davis v. City of New Yurk, 119 F.24 559 (2d Cir. 1941); In re Valade Refrigerator Mifg. Co., 75 F. Supp. 443 (ED. Mich. 1947); In re Famous Furniture Co., 42 F. Supp. 777 (E.D.N.Y. 1942). 
bankruptcy, must be postponed in payment to the first two priorities of $64 \mathrm{at}^{8}$ All other state and federal statutory liens on personal property, which are not enforced by sale prior to bankruptcy ${ }^{\circ}$ and are not accompanied by possession, ${ }^{10}$ must also be postponed in the same manner..$^{11}$ When rent or wage liens are so subordinated, they are paid only to the extent permitted for the 64a rent and wage priorities. ${ }^{12}$ Nevertheless, subordinated statutory lienors are likely to fare better than if they never had a lien; without a lien an

8. See In re Henry, 49 F. Supp. 957 (W.D. Pa. 1943); In re Jay \& Dee Store Co., 37 F. Supp. 989 (E.D. Pa. 1941), concurring opinion, 39 F. Supp. 588 (1941) ; In rc Lebed, 39 F. Supp. 457 (E.D. Pa. 1941).

Landlords have sought to avoid postponement by avoiding the label of "lien of distress for rent." Compare In re Kocialek, 32 F. Supp. 228 (M.D. Pa. 1940), with In re Lebed, 39 F. Supp. 457 (E.D. Pa. 1941). See also In re Allen, 92 F. Supp. 717 (S.D. Tex. 1950); 4 Collier, Banruptcy 164 n.40 (14th ed., Moore, 1942).

9. If encumbered property is sold before the bankruptcy petition is filed, the lien is not affected. In re Valade Refrigerator Mfg. Co., 75 F. Supp. 443 (E.D. Mich. 1947); Itt re Kentucky Book Mfg. Co., 30 F. Supp. 400 (W.D. Ky. 1939).

10. Absence of possession resulted in postponement in the following cases: City of Dallas v. Crippen, 171 F.2d 526 (5th Cir. 1948) ; City of New York v. Hall, 139 F.2d 935 (2d Cir. 1944) ; In re Burch, 89 F. Supp. 249 (D. Kan. 1948); In $r c$ Empire Granite Co., 42 F. Supp. 450 (M.D. Ga. 1942); In re Auto Electric \& Repair Parts Co., 41 11. Supp. 3 (W.D. Ky. 1941); In re Penticoff, 36 F. Supp. 1 (D. Mlinn. 1941).

Possession allowed lienor to escape postponement in the following cases: Goggin v. Division of Labor Law Enforcement of California, 336 U.S. 118 (1943) ; United States v. Sands, 174 F.2d 384 (2d Cir. 1949). Cf. Gordon v. Sullivan, 188 F.2d 980 (D.C. Cir. 1950).

11. Postponed liens are usually ranked in the same order they would have had if not postponed. The order is governed by applicable state and federal statutes. In re Burch, 89 F. Supp. 249 (D. Kan. 1948); In re Auto Electric \& Repair Parts Co., 41 F. Supp. 3 (W.D. Ky. 1941). Cf. Adams v. O'Malley 182 F.2d 925 (8th Cir. 1950).

Postponement protects clains for bankruptcy administration expenses, and wage claims up to $\$ 600$ per claimant. ANalysis of H.R. 12889, 74th Cong., 2d Sess. 212 (1936). Scc City of New York v. Hall, 139 F.2d 935, 936 (2d Cir. 1944); In re Jay \& Dee Store Co., 37 F. Supp. 989, 991 (E.D. Pa. 1941).

One result of postponing a lien might be to allow an unpostponed junior lien on the same property to pre-empt payment of administration expenses and small wage claims. See New Orleans v. Harrell, 134 F.2d 399 (5th Cir. 1943); It re Empire Granite Co., 42 F. Supp. 450 (M.D. Ga. 1942).

12. Wage claims are restricted to the amount earned within three months prior to the commencement of the bankruptcy proceeding, not to exceed $\$ 600$ per claimant. Rent claims are restricted to the amount accrued within three months before the date of bankruptcy. 52 Stat. 874 (1938), 11 U.S.C. \& 104(a) (1946).

Restriction aims at protection of general creditors from exhaustion of the bankrupt's estate. ANalysis of H.R. 12889, 74th Cong., 2d Sess. 201 (1936) ; H.R. Rer. No. 1409, 75th Cong., 1st Sess. 15-16 (1937). It was not intended that a lien be restricted for the benefit of other liens, so the Chandler Act provided for restriction "except as against other liens." This provision proved inadequate to protect general creditors. In re Eakin Lumber Co., 39 F. Supp. 787 (N.D. W. Va. 1941), aff'd sub nom. R.F.C. v. Sun Lumber Co., 126 F.2d 731 (4th Cir. 1942); In re Michael's Cafeteria, 49 F. Supp. 657 (W.D. La. 1943), modified on rehearing, 52 F. Supp. 799 (D. La. 1943). A new amendment to 67 (c) 
ordinary claimant will share with general creditors after all $6 t_{a}$ priorities are paid. And even if subordinated lienors themselves are entitled to a 643 priority, they would, with the exception of wage claimants (who possess a second priority anyway), ${ }^{13}$ receive a higher rank in the order of payment. By virtue of their subordinated liens, landlords, otherwise usually entitled to a fifth priority, ${ }^{14}$ take precedence over the third priority (creditors' expenses of proving the debtor's misconduct in the bankruptcy proceedings) ${ }^{\mathbf{1 5}}$ and the fourth priority (tax claims). ${ }^{10}$ This elevation may enhance the claimant's chances of recovery since tax claims often talie a large bite of the debtor's remaining assets. ${ }^{17}$ Tax claims, normally accorded a fourth priority in the absence of a lien, rise above the third priority too. This jump itself is likely to be inconsequential because of the typically low claims of the third priority. ${ }^{18}$ But the amount allowed on the tax claims may be increased, the fourth priority specifying that "no order shall be made for the payment of a tax assessed against any property of the bankrupt in excess of the value of the interest of the bankrupt estate therein" is interpreted by some courts to mean that the excess of a tax claim should not even be allowed as a general claim. ${ }^{13}$ Since $67 \mathrm{c}$ contains no similar proscription, the excess of a suliordinated tax lien might be paid as a general claim.

In 1952, Congress again critically considered state statutory liens and restricted them further. ${ }^{20}$ Former $67 \mathrm{c}$ became $67 \mathrm{c}(1)$ and subdivision (2) was added, which provides that:

"[S]tatutory liens created or recognized by the laws of any State for debts owing to any person, including any State or any subdivision

now permits the trustee to "tale over" the excess of restrictcd liens as well as the cntire amount of liens voided by 67 (c) (2) (see text at p. 1134 infra) for the benefit of the estate. This clearly makes restrictions serve the interests of the general creditors. 6 STAT. 427, 11 U.S.C.A. \$ 107 (c) (Supp. 1952).

13. 52 Stat. 874 (1938), 11 U.S.C. $\$ 104$ (a) (2) (1946); In re Empire Granite Co., 42 F. Supp. 450 (M.D. Ga. 1942) ; In ri Auto Electric and Repair Parts Co., 41 F. Sugp. 3 (W.D. Ky. 1941); In re Penticoff, 36 F. Supp. 1 (D. Minn. 1941).

14. The fifth priority includes landlords' claims for rent only if they are entitled to priority under state law. 52 ST.1T. 874 (1938), 11 U.S.C. $\$ 104$ (a) (5) (1946).

15. 52 St.AT. 874 (1938), as amended, 63 St.r. 108 (1949), 11 U.S.C..1. $\$ 104(3)$ (3) (Supp. 1952).

16. 52 Stat. 874 (1938), 11 U.S.C. $\$ 104(a)(4)$ (1946).

17. See 4 Colifer, Eankruptcy 163 (14th ed., Mioore, 1943).

18. Ibid.

19. See cases and discussion in Mfooke \& Countryanan, Dextons' and Crentrons" RIGHTS 1073 n.4 (1951).

20. 66 Stat. 427, 11 U.S.C.A. $\$ 107$ (c) (Supp. 1952). This time Congress was apparently aiming at state liens which attach to a debtur's property generally, termed "Boating liens." Such liens, it vas felt, are indistinguishable from priorities; the favered creditor asserts the full amount of his claim against all the property in the estate at the time of bankruptey and is paid before general creditors. H.R. IEEs. No. 2320, 82d Cong., 2d Sess. 13 (1952). 
thereof, on personal property not accompanied by possession of, or by levy upon or by sequestration or distraint of, such property, shall not be valid against the trustee. . .."21

Liens on personalty not enforced by sale prior to bankruptcy remain within the sweep of $67 \mathrm{c}$. Nor does the 1952 amendment alter the status of nonstatutory liens of distress for rent and federal statutory liens: the former will be subordinated if not already enforced by sale, the latter if not enforced by sale prior to bankruptcy and not accompanied by possession. But $67 \mathrm{c}(1)$, in view of the new subdivision (2), will subordinate state statutory liens not enforced by sale prior to bankruptcy and not accompanied by possession only if they are accompanied by levy, sequestration, or distraint. ${ }^{22}$ Stubdivision (2) invalidates state statutory liens not enforced by sale prior to bankruptcy and not accompanied by possession or by levy, sequestration, or distraint. Thus the significance of the 1952 amendment should be readily apparent to the state statutory lienor: he retains some benefits from his lien if he falls under (1), but is relegated to the status of a general creditor if he comes within (2).

Even with the restrictive effect of the 1952 amendment, Section $67 \mathrm{c}$ remains an imperfect implementation of Congress' desire to preserve the Bankruptcy Act's order of payment. Section 67c still appplies only to statutory liens on personalty; yet statutory liens on realty may constitute a greater threat to the Act's payment scheme since they probably consume a larger share of the bankrupt's estate. ${ }^{23}$ Moreover, holders of statutory liens on personalty may continue to disrupt the hierarchy of payment. Statutory lienors can escape $67 \mathrm{c}$ completely by foreclosing their liens prior to bankruptcy, or, with the exception of landlords with a lien of distress for rent, by obtaining possession of the encumbered property; and while the federal government as tax lienor qualifies for $67 \mathrm{c}(1)$ without taking any steps to protect its lien, state statutory lienors can come under $67 \mathrm{c}(1)$ by acquiring a levy, sequestration, or distraint.

21. 66 STaT. 427,11 U.S.C. \& 107 (c) (2) (Supp. 1952).

22. State statutory liens of distress for rent: From an independent reading of the two subdivisions, 67 (c) (1) would apply to all state statutory liens of distress for rent. Y(t 67 (c) (2) covers some of the same ground, since it applies to state statutory liens of distress for rent not accompanied by possession, levy, sequestration, or distraint. A harmoniou: interpretation of the subdivisions requires 67 (c) (1) to be read as applicable, not to all state statutory liens of distress for rent, but only to those accompanied by either possessiun, levy, sequestration, or distraint: all others fall under 67 (c) (2).

State statutory non-rent licns: While both subdivisions apply to non-rent state statutory liens only when the lienor has no possession, 67 (c) (2) does not come into play unless the lienor also lacks levy, sequestration, or distraint. On a literal reading of the statute, 67 (c) (1) would seem to apply to liens that fall under 67 (c) (2), since such liens would not be accompanied by possession. To avoid this, the subdivision must be read so that liens not accompanied by possession fall under 67 (c) (1) only when levy, sequestration, or distraint is present: in their absence, such liens are within the exclusive jurisdiction of $67(\mathrm{c})(2)$.

23. See 4 Collier, Banruptcy 166 (14th ed., Moore, 1942). 
But $67 \mathrm{c}(2)$ may have been enacted to encourage statutory lienors to give public notice of the existence of their liens, in order to prevent extension of credit on encumbered property by unsuspecting creditors. 24 This goal, however, is incompatible with the section's primary objective. To the extent creditors receive public notice through possession, levy, sequestration, or distraint, the Act's hierarchy of payment will be upset: maximum attainment of the notoriety aim will cause maximum interference with the Act's payment scheme. Aside from this incompatibility of aims, the section's ability to promote notoriety of liens is probably limited. Since the section is restricted to liens on personalty, $67 \mathrm{c}(2)$ does not encourage public notice of realty liens. In fact, $67 \mathrm{~b}$ may allow perfection of realty liens after bankruptcy if the state statutory period for perfection has not elapsed. ${ }^{25}$ Moreover, even as to statutory liens on personalty. 67c ignores public notice by recordation. Some states allow or require perfection in this way. ${ }^{23}$ And recordation, especially in states where it is the required method of perfection, might provide more effective notice than possession, levy, sequestration, or distraint.

The increasing antipathy toward statutory liens on personalty, evidenced by the 1938 and 1952 amendments to the Act, may signal a trend toward complete withdrawal of protection for such liens in bankruptcy proceedings. Such a goal seems eminently desirable. The Act now offers $64_{2}$ priorities to groups that are generally thought to merit special consideration: wage earners, landlords, state and federal taxing authorities. Congress could enaet additional priorities if other creditors were thought deserving of special treat-

24. It is not clear that the Chandler Act provision was intended to promote natice. The National Bankruptcy Conference Report, Avalysis or H.R. 12889, 74th Cong., 2d Sess. 212 (1936), does not indicate this purpose, nor does the Committee Report on the Chandler Act, H.R REP. No. 1409, 75th Cong., 1st Sess. (1937). But several courts have suggested "notice" as an aim of the section. Sce Goggin v. Division of Lator Law Enforcement of California, 336 U.S. 118, $127-9$ (1949); City of New York v. Hall, 139 F.2d 935, 936 (2d Cir. 1944). The 1952 House of Representatives Committee Renort hints that notice was intended; and to explain why liens on realty were not made subject to 67 (c), it states: "A lien upon real estate is commonly dealt with adcquately by recording acts. ..." H.R. REP. No. 2320, S2d Cong., 2d Sess. 13 (1952). Since the primary function of recording is notice, this implies that notice was a goal of 67 (c).

It is possible that notice was not an objective of the Chandler Act, and that the notion was voiced in the cases by judges who, in other situations, were accustomed to viewing possession as a means of giving notice.

25. E.g., In re Taylorcraft Aviation Corp., 16S F.2d 808 (6th Cir. 1948).

26. Most wage liens require recording within a specified time to prevent expiration of the lien. See R.F.C. v. Sun Lumber Co., 120 F.2d 731, 739 (4th Cir. 1942); In re Pennsylvania Central Brewing Co., 11+ F.2d 1010, 1012-3 (3d Cir. 1940), corb. desicd sub mon. Stern v. Pennsylvania Brewing Co., 312 U.S. 685 (1941); In re Empire Granite Co., 42 F. Supp. 450, 454 (M.D. Ga. 1942). "Perfection" or "fixing" of liens often means recording. See ILI. ANN. Stat. c. $\$ 2, \$ \S 41-2,52$ (Smith-Hurd, 1935); id. $\$ \S 78,97$ (Supp. 1952) ; 5 Ohio GEx. Cone ANw. $\$ \$ ~ \$ 324,8332,8340$, 8378 (Page, 1938); 16 TEx. Civ. Stat. AnN. tit. 90, arts. 5453, 5476, 5486 (Vernon, 1925). 
ment. However, even limited recognition of statutory liens abdicates to the states the responsibility for defining the range of needy creditor groups. As a result, uniformity among the states is lost, and some creditors may benefit to the detriment of others who, in Congress' mind, are equally deserving. And these considerations apply to statutory liens on realty as well as personalty. Judicious use of the power to enact 64a priorities may be a simple and effective substitute for the patchwork that is now $67 \mathrm{~b}$ and $67 \mathrm{c}$.

John B. Marshall†

$\dagger$ Member of the Class of 1954, Yale Law School. 